\title{
Predictive Parameters for Clinical Outcome in Patients with Critical Limb Ischemia Who Underwent Percutaneous Transluminal Angioplasty (PTA): A Systematic Review
}

\author{
Sanne M. Schreuder ${ }^{1}$ - Yvette M.G.A. Hendrix ${ }^{1} \cdot$ Jim A. Reekers $^{1}$ • \\ Shandra Bipat ${ }^{1}$
}

Received: 9 June 2017/ Accepted: 6 September 2017/Published online: 18 September 2017

(c) The Author(s) 2017. This article is an open access publication

\begin{abstract}
Purpose To identify possible risk factors in predicting clinical outcome in critical limb ischemia (CLI) patients undergoing percutaneous transluminal angioplasty (PTA). Materials and Methods PubMed and EMBASE were searched for studies analyzing CLI and clinical outcome after PTA from January 2006 to April 2017. Outcome measures were ulcer healing, amputation free survival (AFS)/limb salvage and overall survival. Data on predictive factors for ulcer healing, AFS/limb salvage and survival were extracted.

Results Ten articles with a total of 2448 patients were included, all cohorts and based on prospective-designed databases. For ulcers, it seems that complete healing can be achieved in most of the patients within 1 year. No significant predictive factors were found. AFS/limb salvage: AFS rates for 1, 2 and 3 years ranged from 49.5 to $75.2 \%$, 37 to $58 \%$ and 22 to $59 \%$, respectively. Limb salvage rates for 1, 2 and 3 years ranged from 71 to $95 \%, 54$ to $93.3 \%$ and 32 to $92.7 \%$, respectively. All studies had different univariate and multivariate outcomes for predictive factors; however, age and diabetes were significant predictors in at least three studies. Survival: Survival rates for 1, 2 and 3 years ranged from 65.4 to $91.5 \%, 45.7$ to $76 \%$ and 37.3 to $83.1 \%$, respectively. Different predictive factors were found; however, age was found in 2 out of 5 studies reporting on predictive factors.
\end{abstract}

Sanne M. Schreuder

s.m.schreuder@amc.uva.nl

1 Department of Radiology and Nuclear Medicine, Academic Medical Center, University of Amsterdam, Meibergdreef 9, 1105 AZ Amsterdam, The Netherlands
Conclusions In several studies two factors, age and diabetes, were found as predictive factors for AFS/limb salvage and survival in patients with CLI undergoing PTA. Therefore, we believe that these factors should be taken into account in future research.

Level of Evidence Level 2a.

Keywords CLI · PTA · Amputation free survival · Survival

\section{Introduction}

Critical limb ischemia (CLI) due to peripheral arterial disease is a condition in which the lower extremity is threatened and is defined by ischemic rest pain, with or without ischemic tissue loss [1]. CLI has a great impact on healthcare and associated healthcare budget [2]. A number of risk factors are known to be associated with the development of CLI, which are diabetes mellitus, smoking, increased age, lipid abnormalities and low ankle-brachial pressure index [2].

Of the CLI patients, $10-40 \%$ will lose their leg within 6 months and the 1-year mortality rate is $25 \%$ in CLI patients who are not able to be revascularized [2-4].

Percutaneous transluminal angioplasty (PTA), with or without stenting, is an alternative approach to surgical bypass as a revascularization method in patients with CLI $[5,6]$. Compared to surgery, it involves advantages such as minimal access trauma and shorter hospital stay. Therefore, PTA is more suited and often suggested as first-line therapy for highrisk CLI patients with a lower life expectancy [7-10].

To identify the effect of PTA, clinical outcomes such as wound healing, amputation free survival (AFS) and survival during follow-up are recorded and presented [11-17]. 
However, interpreting these clinical outcomes in this patient group is difficult, because of its heterogeneity in the risk factors such as comorbid diabetes, difference in age, renal failure or lifestyle factors such as smoking and obesity. We often see a discrepancy between a good revascularization result of the PTA, identified on digital subtraction angiography (DSA) and an unexpected poor clinical outcome with early amputation [9, 18, 19]. For future analysis of study results concerning endovascular treatment in CLI patients, it is important to identity which risk factors are associated with poor outcome.

Therefore, the aim of this systematic review was to identify risk factors in predicting poor clinical outcome in patients with CLI undergoing PTA with or without stenting. Drug eluting technologies were not included in the review to try to maintain homogeneity in the study population.

\section{Materials and Methods}

This review was conducted according to the preferred reporting items for systematic review and meta-analysis (PRISMA) guidelines [20]. The review protocol was not published or registered in advance.

\section{Search Strategy}

An electronic search was performed in the databases PubMed and EMBASE for studies analyzing CLI and clinical outcome after percutaneous revascularization. The search period was from January 2006 to April 2017. Search terms used for PubMed and EMBASE are listed below.

PubMed "Critical limb ischemia OR critical limb ischemia AND (angioplasty OR endovascular revascularization OR percutaneous intentional extraluminal revascularization OR subintimal OR endovascular therapy) AND (major amputation OR amputation free survival OR death OR ulcer healing OR wound healing OR mortality OR survival) AND Humans".

Embase: (Critical limb ischamia OR critical limb ischemia) AND (percutaneous transluminal angioplasty balloon OR percutaneous transluminal angioplasty OR angioplasty OR stent OR revascularization) AND mortality OR (amputation OR major amputation OR leg amputation) OR (ulcer healing OR wound healing) OR (survival).

\section{Study Selection}

Step 1 All retrieved articles were checked on title and abstract by one observer (X2). Duplicates, reviews, guidelines, comments, letters to the editor, conferences, case reports, study protocol and articles not containing CLI were excluded.
Step 2 All remaining articles were also checked on abstract by the same observer (X2). When studies contained less than fifty patients, patients did not receive PTA, the study was retrospective (we considered prospective database as prospective study) or the follow-up period was less than 1 year, these studies were excluded. To avoid exclusion of relevant articles, ambiguous articles were retrieved as full text and treated as potentially eligible articles. The observer double-checked step 2 and was not blinded to author and journal names.

\section{Inclusion of Relevant Articles}

Three observers (X1, X2 and X3) independently checked all remaining articles for inclusion and exclusion criteria. Two observers (X1 and X2) each checked half of the relevant articles, and the findings were discussed with observer 3 (X3) who has experience on data extraction of 25 meta-analyses.

The inclusion criteria were as follows: (1) prospective study or prospective database (we considered prospective database as prospective study, hospital billing and other registries as retrospective); (2) patients with CLI as defined by Fontaine class III-IV or Rutherford class IV-VI (rest pain, non-healing ulcer or gangrene); (3) patients underwent (regular) PTA (no drug eluting stents); (4) $>50$ patients with CLI undergoing PTA; (5) data on outcome were available for at least 1 year of follow-up (outcomes were healing, AFS (major of minor) and overall survival); (6) separate data on CLI and PTA were available (in studies that included a variety of patients or treatments, for example data on CLI patient who underwent PTA or bypass surgery); and (7) finally, data on predictive factors were reported. Exclusion criterion was duplicate data.

\section{Data Extraction}

Two reviewers (X1, radiologist with experience in extracting data of two reviews and $\mathrm{X} 2$, medical student) used a standardized form to extract data independently on study design characteristics, patient selection, baseline patient characteristics, procedure description, angiographic outcomes and complications, follow-up and dropout patients, clinical outcomes and predictive factors. Again, each observer extracted data of half of the articles and were double-checked by the third reviewer with experience on data extraction of 25 meta-analyses.

Study design characteristics The following data on study design characteristics were extracted: (1) study type (cohort, part of RCT or other); (2) study design (single center or multicenter and prospective study or prospective database retrospectively analyzed); (3) setting initiation institute (academic, tertiary or other); (4) department 
Total hits: 1,635

(PubMed: 734 / EMBASE: 901)

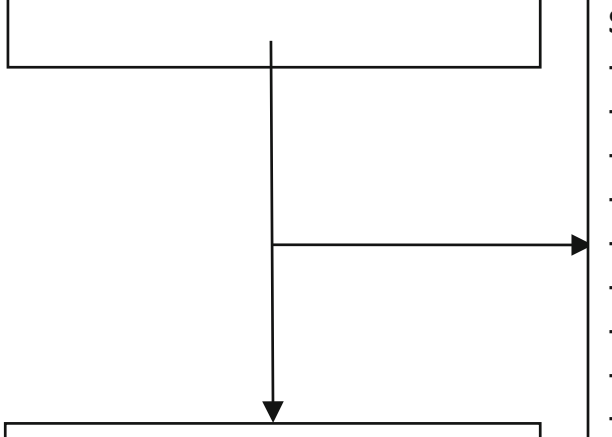

Step 1: Exclusion based on title and abstract: $(n=1,010)$

- Duplicates: 240

- Letters/comments/editorials: 57

- Conferences: 354

- Case reports: 42

Other languages (Chinese, Korean, Japanese, Russian, Spanish): 38

- Reviews / guidelines: 228

- Study protocols: 7

- $\quad$ Not relevant (no CLI patients): 37

- No access: 7

625 Articles on CLI patients

Step 2: Exclusion based on title and abstract (and full-text): ( $n=442)$

- Less than $n=50$ patients included: 136

Patients not undergoing EVT / PTA: 152

Retrospective analysis: 146

Less than 1 year follow up: 8

183 Potentially relevant articles

Step 3: Excluded based on inclusion and exclusion criteria (full text): ( $n=173)$

- $\quad$ Retrospective analysis: 47

- No CLI patients: 2

- Patients did not undergo (regular) PTA: $22^{a}$

- $\quad$ Less than fifty patients with CLI undergoing PTA: 14

- $\quad$ No relevant data (ulcer healing, amputation free survival or survival) for PTA available for at least one year of follow up: 47

- Relevant data on PTA were not mentioned separately: $11^{\text {b }}$

- $\quad$ No data on predictive factors: 29

10 Articles included in the analysis

Duplicate data: 1

Fig. 1 Search, selection and inclusion of relevant articles. ${ }^{a}$ Patients did not undergo primary or standard PTA (e.g., use of primary stenting or drug eluting stent) or it was not clear what number of

initiation by first author (radiology, surgery or other); (5) period of recruitment; (6) institutional review board approval (approved and informed consent obtained/waived, not approved or unclear); and (7) funding or a potential role of funders in the study (conflict of interest).

Patient selection The following data on patient selection were retrieved: (1) consecutive sample of patients enrolled (yes or no); (2) inclusion and exclusion criteria defined; and (3) spectrum of patients representative for CLI patients normally receiving PTA.

Baseline patient characteristics There were no age limits applied regarding patients. The following data on patients did undergo PTA. ${ }^{\mathrm{b}}$ In several studies patients did undergo PTA; however, no data were separately mentioned from other procedures (e.g., bypass surgery)

patient population were extracted: (1) number of patients included in the study and (2) analyzed in the final analysis; (3) age of patients (mean $\pm \mathrm{SD}$, median and/or range); (4) male-to-female ratio; (5) smoking $(n+$ percentage); (6) diabetes mellitus $(n+$ percentage $) ;(7)$ hypertension $(n+$ percentage $) ;(8)$ dyslipidaemia $(n+$ percentage $) ;(9)$ renal failure $(n+$ percentage); (10) coronary artery disease $(n+$ percentage $)$; (11) stroke history $(n+$ percentage); (12) $\mathrm{BMI}<18,5 \mathrm{~kg} / \mathrm{m} 2(n+$ percentage $)$; (13) other factors $(n+$ percentage); (14) other baseline characteristics such as ankle-brachial index (ABI), toe pressure (mean $\pm \mathrm{SD}$ in $\mathrm{mmHg}$ ), ankle pressure, $\mathrm{TcPO} 2$ 
(mean $\pm \mathrm{SD}$ in $\mathrm{mmHg})$, ulcer classification $(n+$ percentage), Fontaine classification (III or IV), Rutherford classification (IV, V and VI) and other characteristics when cited; and (15) anticoagulation/antiplatelet medication at baseline $(n+$ percentage).

Procedure description The following data were extracted: (1) who performed the procedure (interventional radiologist, vascular surgeon or other); (2) experience defined (number of procedures performed or years of experience); (3) which procedure was performed (only PTA (balloon), PTA + stent placement or other); and (4) if the study was described in sufficient detail to permit its replication (if information was provided as stated in previous items $1-3$ ).

Angiographic outcomes and complications data were extracted on how articles defined (1) technical success; (2) partial success/failure; (3) complete technical failure; (4) major complications; and (5) minor complications and how many successes, failures and complications occurred.

Follow-up and dropout patients The following data were extracted regarding follow-up: (1) a summary of follow-up time and scheme; (2) if all patients underwent the same follow-up (yes or no) and (3) were dropout patients adequately reported (yes or no, with or without reasons for dropout or unclear).

Clinical outcomes and predictive factors Data were extracted on the three previously defined outcome variables: (1) ulcer healing; (2) AFS (major of minor) or limb salvage and (3) overall survival at baseline and at least 1-year follow-up with a maximum of 5-year follow-up. Data on predictive factors either in terms of regression analysis (univariate or multivariate) were extracted.

\section{Data Analysis}

All data at baseline were presented as number plus percentage, with the exception of age, which is presented as a mean. Because standard deviation was not available in all datasets, result on baseline could not be pooled.

Data on ulcer healing, AFS and overall survival at baseline and at least 1-year follow-up were recorded. Data on predictive factors for ulcer healing, AFS (also limb salvage) and survival were extracted as reported in papers. As anticipated, the number of studies was limited. The data were heterogeneously presented so even meta-analysis with random effect approach would not be suitable for pooling predictive values. All data are therefore presented per study.

\section{Results}

\section{Search, Selection and Inclusion of Relevant Articles}

The search yielded 1635 studies: 734 from Pubmed and 901 from EMBASE (see Appendix 1).

After excluding duplicates (240), letters/comments/editorials (57), conferences (354), case reports (42), other languages than English, Dutch, French or German (38), reviews and guidelines (228), study protocols (7), articles not involving CLI (37) and seven articles of which the full article could not be obtained, 625 articles on CLI remained.

Subsequently, articles were excluded based on title and abstract because they had less than 50 patients (136), they did not undergo PTA (152), were retrospective in nature (146) or had less than 1 year of follow-up (8) which yielded 183 potentially relevant articles. Full texts of these articles were checked on inclusion criteria: 173 articles did not meet the inclusion criteria and ten studies were included for data extraction (see Fig. 1) [21-30].

\section{Study Design Characteristics}

Of the ten articles included, all were cohort studies; most studies were performed based on prospective-designed databases and were single center. In all studies, there was no role of funders (see Table 1).

\section{Patient Selection}

The patient selection was consecutive in most of the studies. In all studies, patients were included with CLI; however, the spectrum of patients was equivocal, as in one study only patients $>80$ years were included [21], only diabetic patients [22], only hemodialysis patients [27] or patients with Rutherford V and VI [28] (see Table 2).

\section{Baseline Patient Characteristics}

In total, 2448 patients were included who were CLI patients and underwent PTA with or without bare metal stent placement. Mean ages ranged from 50 to 85.9 years. Male-to-female ratio was $816: 534$ in the seven studies mentioning this ratio [21-23, 27-30]. In addition, a broad range of risk factors was present: smoking rate from 6.9 to $58.3 \%$, diabetes from 49.1 to $100 \%$, hypertension from 51.6 to $98 \%$, dyslipidaemia from 21.1 to $65 \%$ and renal disease up to $100 \%$. Other risk factors such as coronary artery disease, cerebrovascular disease and stroke were also present in the majority of patients (see Table 3).

ABI was mentioned in only small number of studies, other measurements such as toe pressure and ankle pressure 
were only mentioned in the study of Strom et al. (toe pressure mean $30 \mathrm{mmHg}$ [range $0-60 \mathrm{mmHg}$ ] and ankle pressure mean $50 \mathrm{mmHg}$ [range $0-60 \mathrm{mmHg}$ ]) [30]. The TcPO2 was not mentioned in any of the studies. The disease severity in terms of Fontaine classification or Rutherford category was described heterogeneously (see Table 4).

\section{Procedure Description, Outcomes and Complications}

In most studies, it was not clear who performed the procedure. Moreover, the experience of the operator was not defined in any of the studies. In none of the studies, the procedure was described in sufficient detail to replicate. The angiographic outcome in terms of technical success was defined well, and complications were reported in detail.

All data on procedure description and outcomes are given in detail in Table 5 .

\section{Follow-Up and Dropout Patients}

The follow-up was not homogeneous, but in general 1 month, 3-, 6- and 12-month follow-up was done. Patients did not undergo the same follow-up in seven studies, while in three studies patients did undergo the same follow-up. Dropout rates are poorly reported. Only one study [24] accurately reported dropouts, with missing baseline information as most frequent reason for dropout. Follow-up ranged from less than 1 month up to 109 months. All details are given in Table 6 .

\section{Clinical Outcomes: Ulcer Healing, AFS/Limb Salvage and Survival}

\section{Ulcer Healing}

In three studies [22, 25, 28], data on ulcer healing were given. It seems that complete healing can be achieved in most of the patients within 1 year $[25,28]$. Details are given in Table 7.

\section{AFS or Limb Salvage}

In all studies [21-30], data on AFS or limb salvage were given. One-year AFS ranged from 49.5 to $75.2 \%$, 2-year AFS from 37 to $58 \%$ and 3-year AFS from 22 to $59 \%$. The limb salvage rates for 1 month, 1 year, 2 year and 3 year range from 95 to $97.4 \%, 71$ to $95 \%, 54$ to $93.3 \%$ and 32 to 92.7\%, respectively. All data are given in Table 8 . 


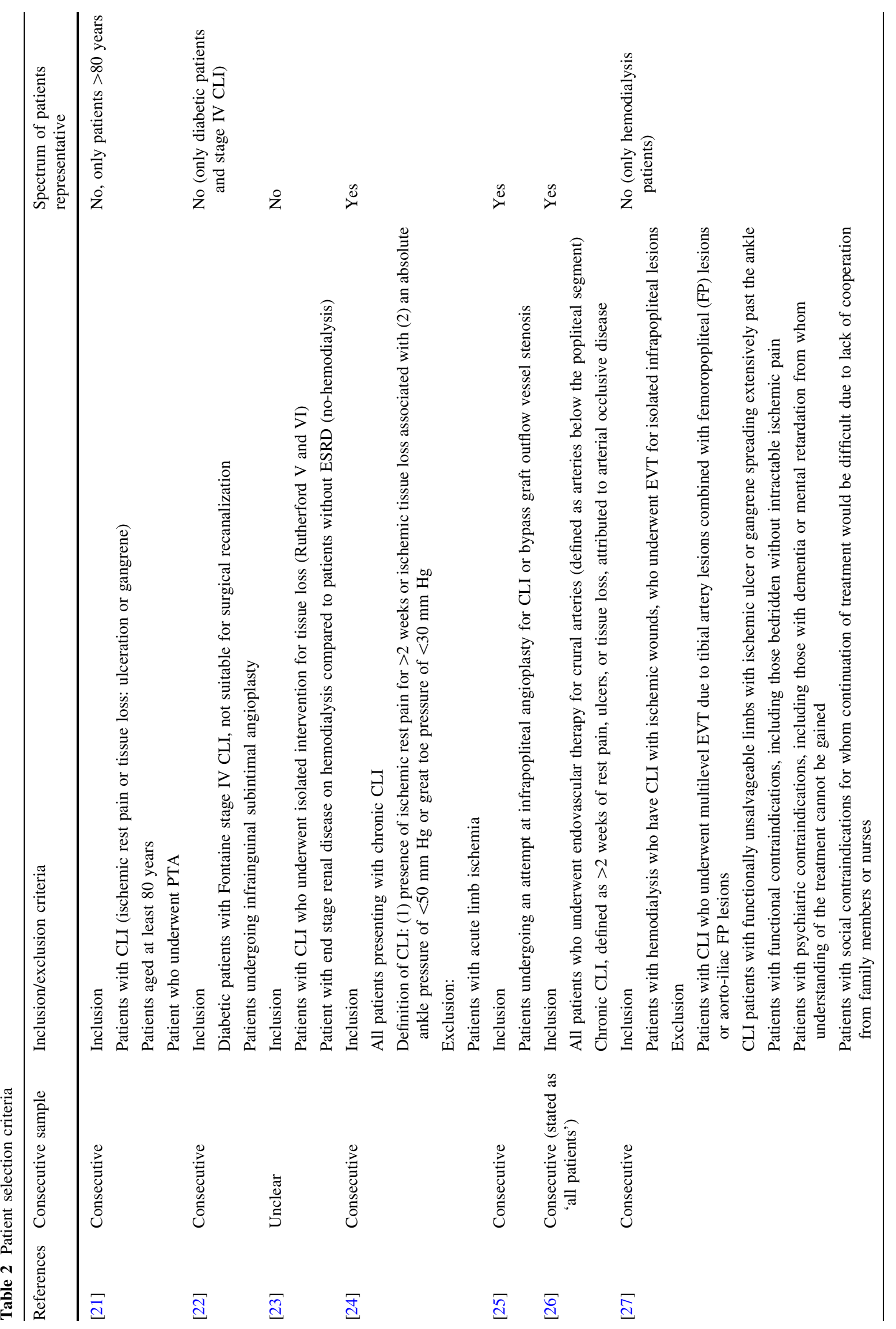




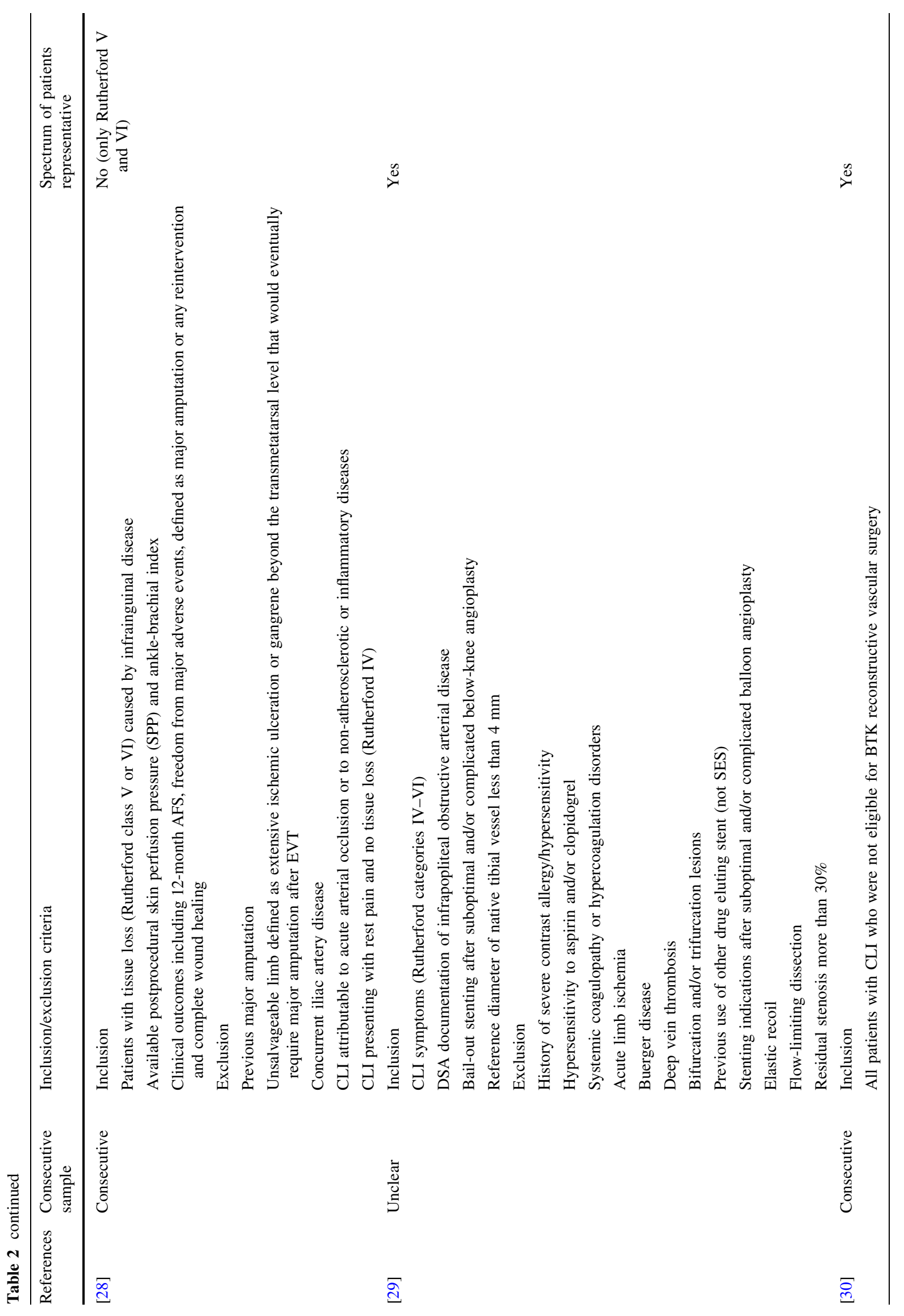




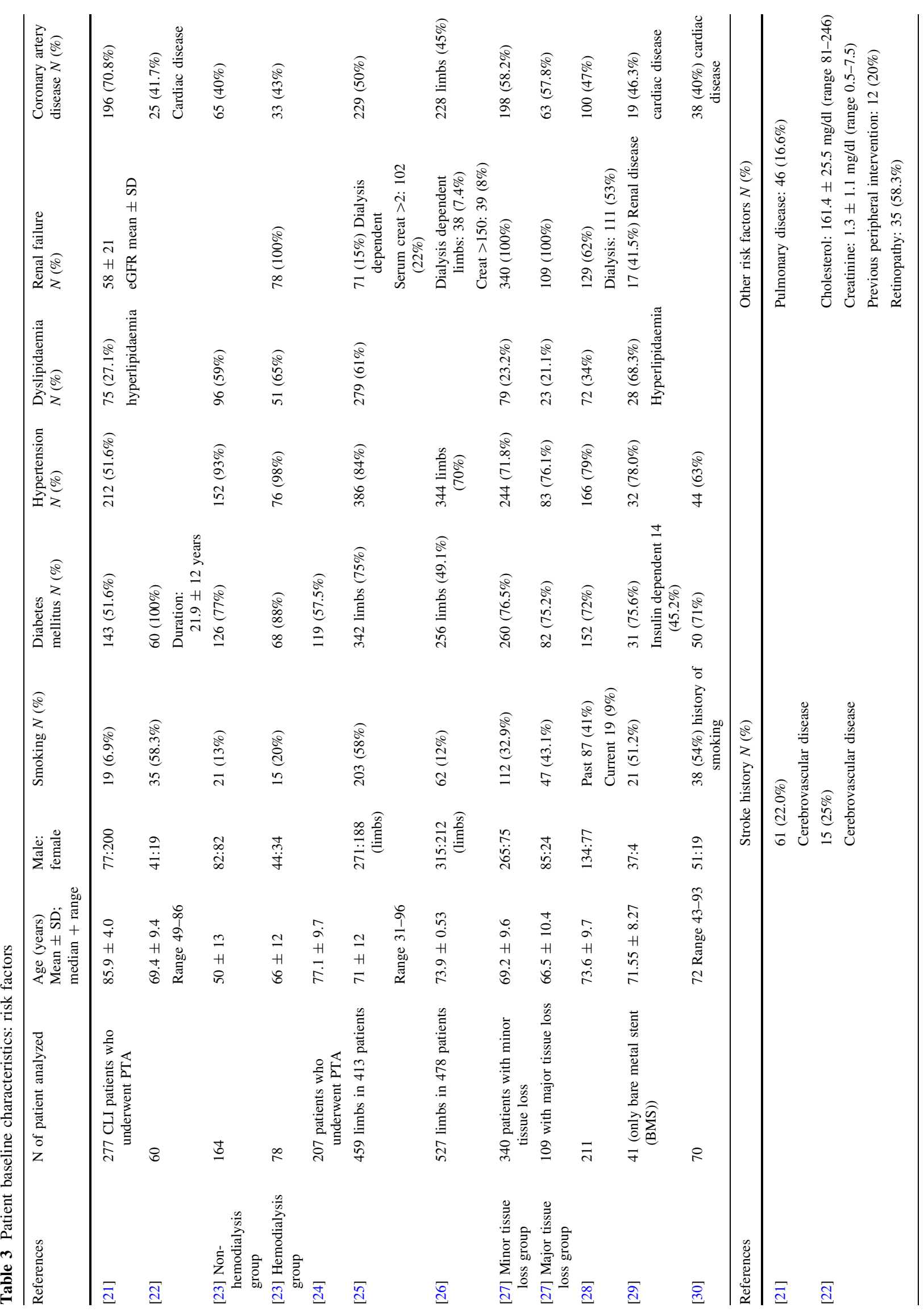




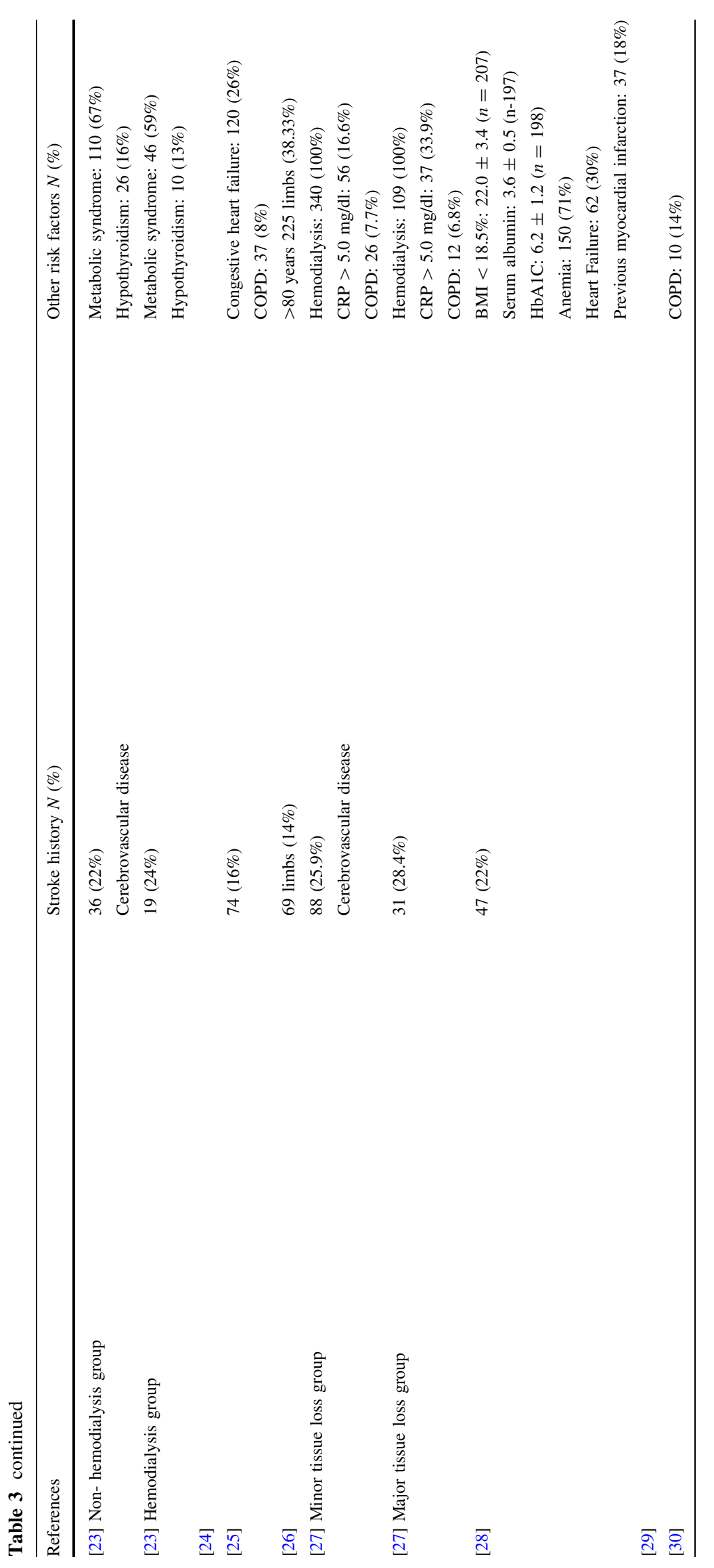




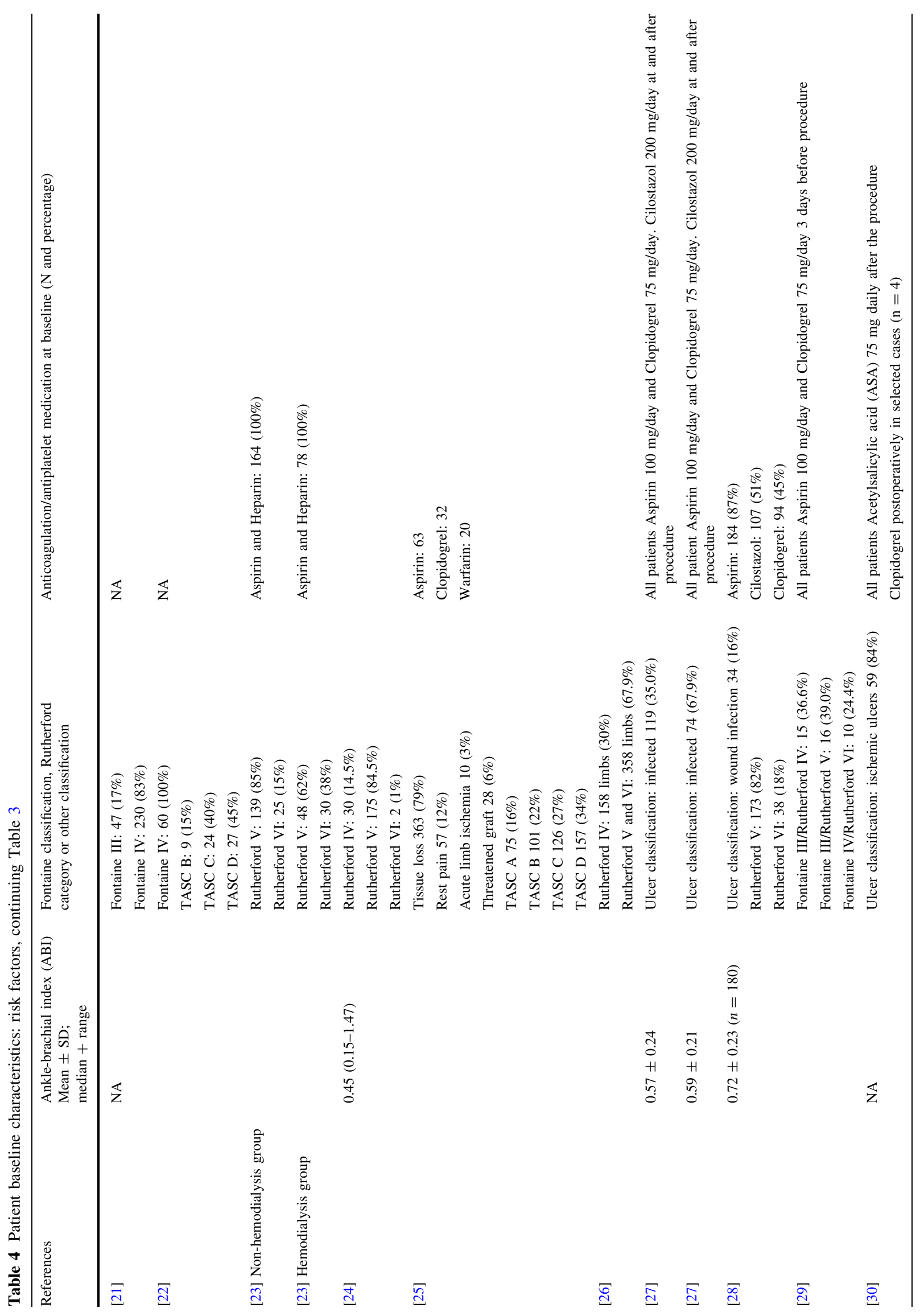




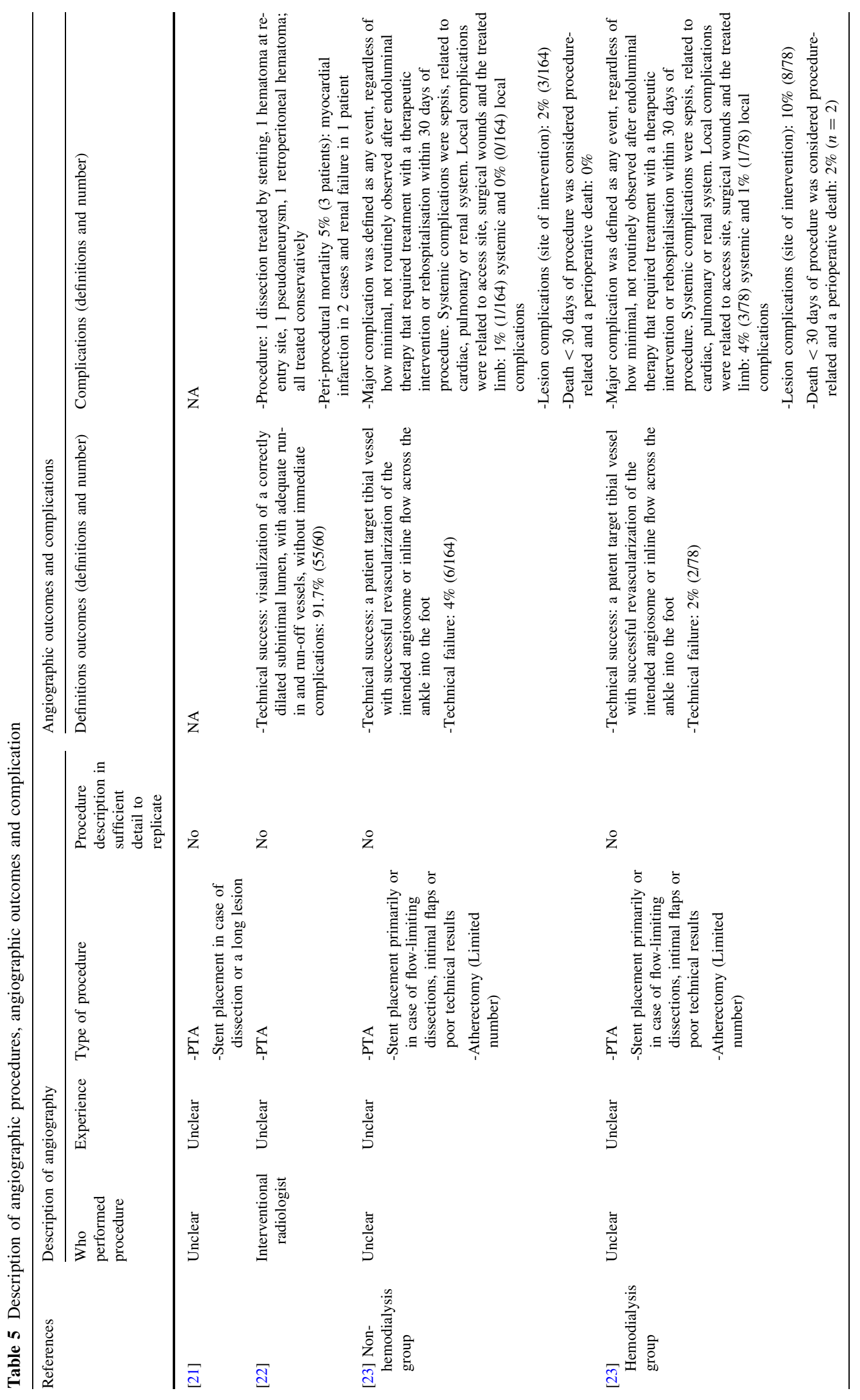




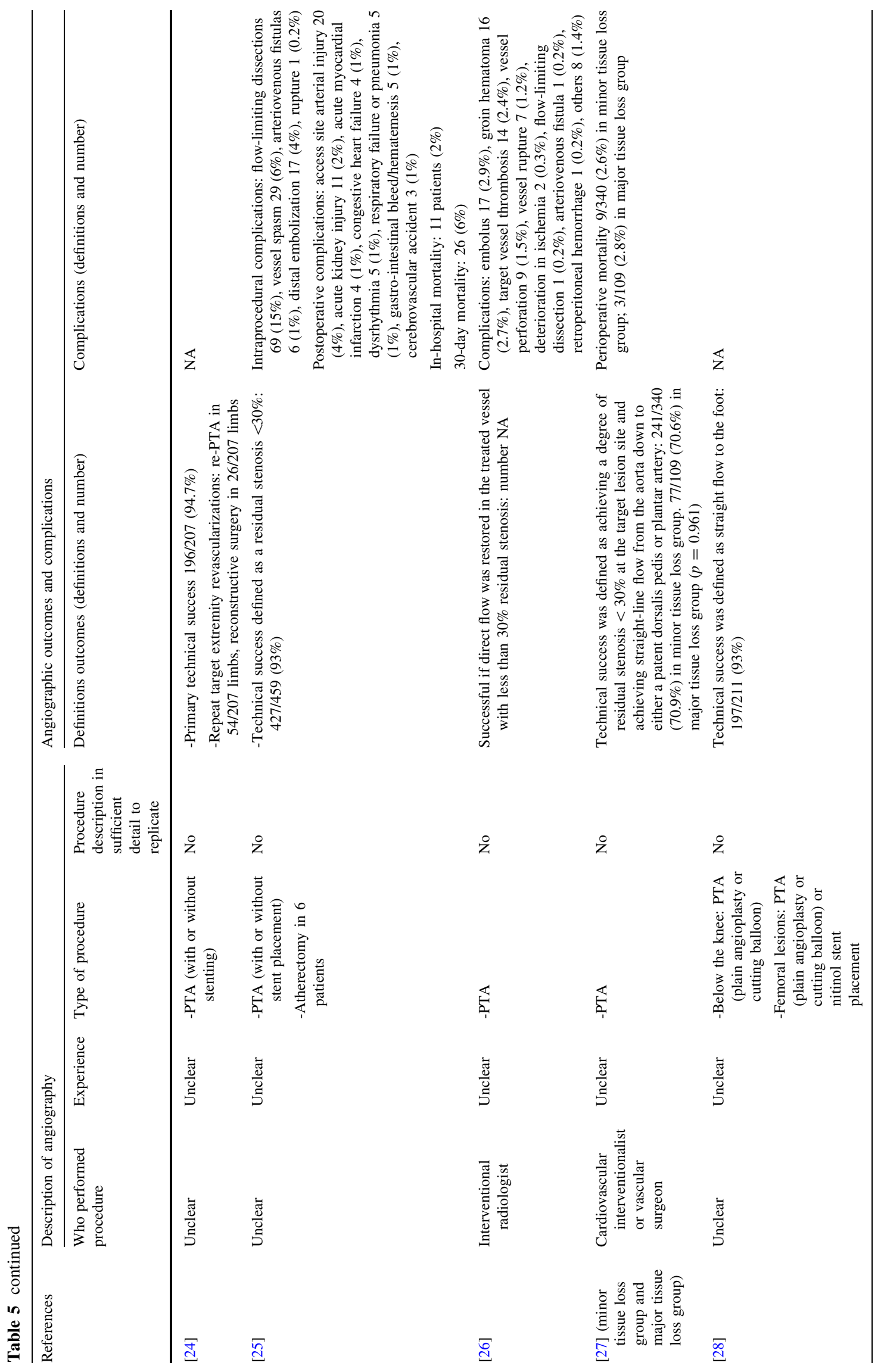




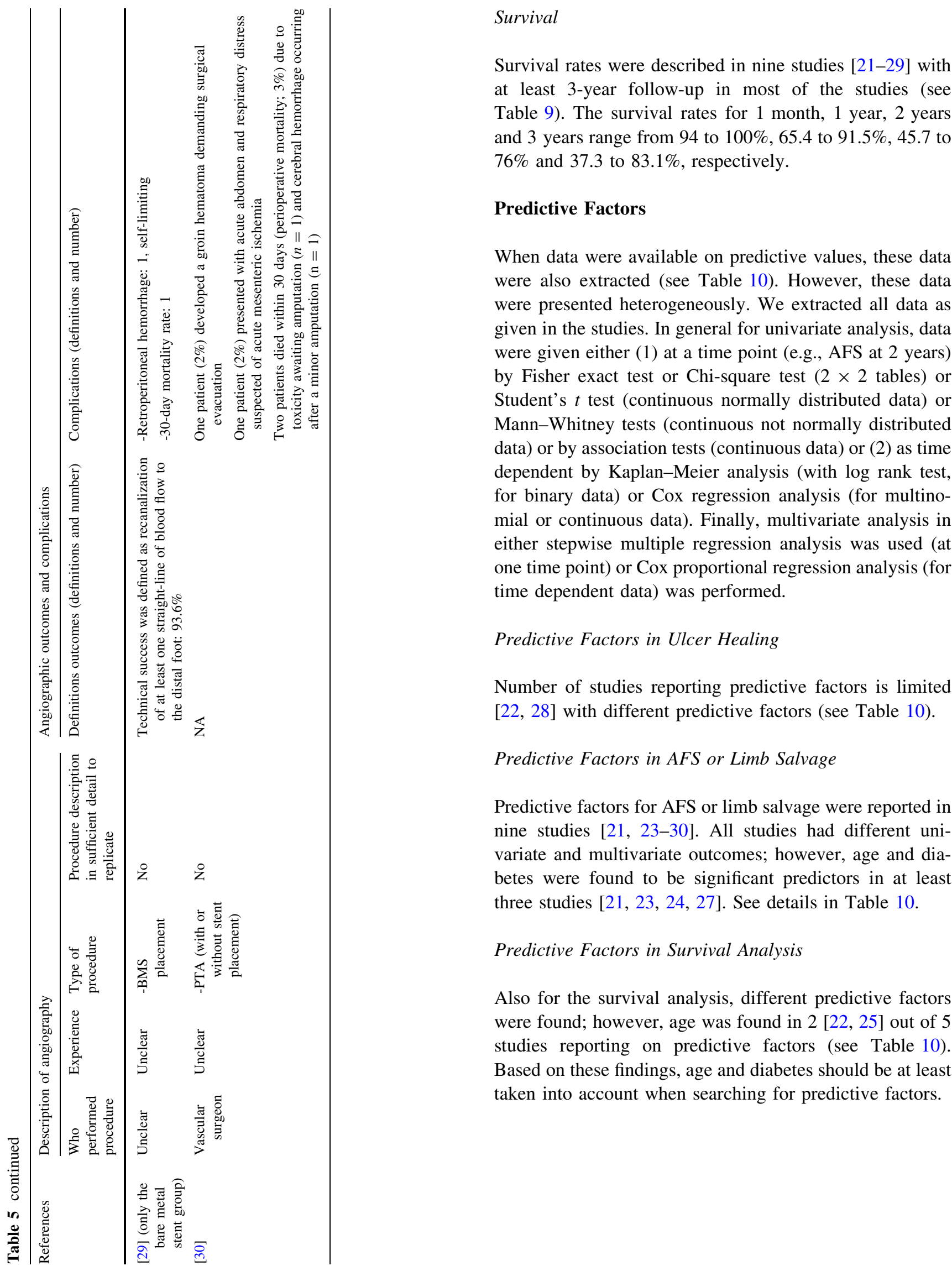


Table 6 Follow-up and dropouts of patients

\begin{tabular}{|c|c|c|c|}
\hline References & $\begin{array}{l}\text { Summarize follow-up } \\
\text { time and scheme }\end{array}$ & Undergo same follow-up & Dropouts reported \\
\hline [21] & $\begin{array}{l}1,6 \text { and } 12 \text { months and } \\
\text { annually thereafter }\end{array}$ & No: mean 2,0 years & $\begin{array}{l}\text { Study registry, dropouts not } \\
\text { reported }\end{array}$ \\
\hline [22] & Not stated & $\begin{array}{l}\text { No: range } 1-48 \text { months, } \\
22.8 \pm 14.9, \text { median } \\
22.5 \text { months }\end{array}$ & None \\
\hline $\begin{array}{l}\text { [23] Non- } \\
\text { hemodialysis and } \\
\text { hemodialysis } \\
\text { group }\end{array}$ & $\begin{array}{l}1,3 \text { and every } 6 \text { months } \\
\text { following their procedure }\end{array}$ & No: means or ranges stated & $\begin{array}{l}\text { Study registry, dropouts not } \\
\text { reported }\end{array}$ \\
\hline [24] & 2, 6 and 12 months & Yes & $\begin{array}{l}\text { Yes (missing baseline } \\
\text { information (10), refusal to } \\
\text { undergo vascular imaging } \\
\text { (2), withdrawal of informed } \\
\text { consent (1), lack of follow- } \\
\text { up data (5) }\end{array}$ \\
\hline [25] & $\begin{array}{l}2 \text { weeks, then every } 3 \text { months } \\
\text { for } 1 \text { year and every } \\
6 \text { months thereafter }\end{array}$ & $\begin{array}{l}\text { No: average } 15 \text { months (range } \\
0-85 \text { months) }\end{array}$ & $\begin{array}{l}\text { Early deaths reported. } \\
\text { Dropouts in further follow- } \\
\text { up are not stated }\end{array}$ \\
\hline [26] & $1,6,12,36$ months & $\begin{array}{l}\text { No: mean } 26.9 \pm 0.54 \text { months, } \\
\text { median } 40 \text { months with a } \\
\text { maximum of } 109 \text { months }\end{array}$ & No \\
\hline [26] & $\begin{array}{l}1,3,6 \text { months and every } \\
3 \text { months thereafter up to } \\
3 \text { years }\end{array}$ & Yes & None \\
\hline [28] & $1,3,6,12$ months & Yes & None \\
\hline [29] & $\begin{array}{l}1,3,6,12 \text { months and yearly } \\
\text { thereafter }\end{array}$ & $\begin{array}{l}\text { No: mean } \\
17.15 \text { months } \pm 1.73 \text {, range } \\
0.7-36 \text { months }\end{array}$ & No \\
\hline [30] & $\begin{array}{l}6 \text { weeks and } 1 \text { year (no } \\
\text { standard FU after } 1 \text { year) }\end{array}$ & $\begin{array}{l}\text { No: median } 20 \text { months (range } \\
0-41 \text { months) }\end{array}$ & None \\
\hline
\end{tabular}

Table 7 Follow-up data on ulcer healing

\begin{tabular}{|c|c|c|c|}
\hline References & 6 months & 1 year & 3 year \\
\hline \multirow[t]{3}{*}{ [22] } & & & Healing 45 (75\%) \\
\hline & & & Improved $7(11.6 \%)$ \\
\hline & & & $\begin{array}{l}\text { Stable } 4(6.7 \%) \text { (Data at latest FU, } \\
\text { however, FU ranges from } 1 \text { to } 48 \text { months) }\end{array}$ \\
\hline \multirow[t]{5}{*}{ [25] } & $N=361$ & $N=192$ & \\
\hline & Complete healing $15 \%$ & Complete healing $63 \%$ & \\
\hline & Improved $55 \%$ & Improved $30 \%$ & \\
\hline & Stable $27 \%$ & Stable $8 \%$ & \\
\hline & Worse $2 \%$ & Worse $0.5 \%$ & \\
\hline \multirow[t]{2}{*}{ [28] } & & $N=164$ & \\
\hline & & $87 \%$ & \\
\hline
\end{tabular}


Table 8 Follow-up data on AFS or limb salvage

\begin{tabular}{|c|c|c|c|c|c|c|}
\hline References & 1 month & 1 year & 2 years & 3 years & 4 years & 5 years \\
\hline \multicolumn{7}{|l|}{ AFS (Amputation free survival) } \\
\hline$[21]$ & $93.1 \%$ & $62.4 \%$ & $53.0 \%$ & $44.3 \%$ & $35.3 \%$ & $32.9 \%$ \\
\hline [23] Non-hemodialysis group & & & & $54 \pm 4 \%$ & & \\
\hline [23] Hemodialysis group & & & & $22 \pm 9 \%$ & & \\
\hline [26] & & $75.2 \%$ & & $59.0 \%$ & & \\
\hline [26] Minor tissue loss group & & $63.5 \pm 2.9 \%$ & $51.0 \pm 3.3 \%$ & $44.1 \pm 3.7 \%$ & & \\
\hline [26] Major tissue loss group & & $49.5 \pm 5.5 \%$ & $37.0 \pm 6.1 \%$ & $29.1 \pm 7.0 \%$ & & \\
\hline$[28]$ & & $73.9 \%$ & & & & \\
\hline$[30]$ & & $68 \%$ & $58 \%$ & & & \\
\hline \multicolumn{7}{|l|}{ Limb salvage } \\
\hline$[21]$ & $97.4 \%$ & $88.8 \%$ & $85.4 \%$ & $82.6 \%$ & $80.2 \%$ & $78.3 \%$ \\
\hline$[22]$ & $\begin{array}{l}95 \% \text { ( } 3 \text { patients, } 5 \% \text { above } \\
\text { knee amputation) }\end{array}$ & $95 \%$ & $93.3 \%$ & & & \\
\hline [23] Non-hemodialysis group & & $76 \pm 3 \%$ & $74 \pm 4 \%$ & $69 \pm 4 \%$ & & \\
\hline [23] Hemodialysis group & & $71 \pm 5 \%$ & $54 \pm 7 \%$ & $32 \pm 8 \%$ & & \\
\hline$[24]$ & $96.5 \%$ & $81 \%$ & & & & \\
\hline$[25]$ & $96 \%$ & $84 \%$ & & & & $81 \%$ \\
\hline [26] & & & & $92.7 \%$ & & \\
\hline [26] Minor tissue loss group & & $87.4 \pm 1.8 \%$ & $84.4 \pm 2.1 \%$ & $83.7 \pm 2.2 \%$ & & \\
\hline [26] Major tissue loss group & & $73.9 \pm 4.3 \%$ & $71.2 \pm 4.5 \%$ & $71.2 \pm 4.5 \%$ & & \\
\hline [29] & & & & $80.3 \%$ & & \\
\hline
\end{tabular}

Table 9 Follow-up data on survival

\begin{tabular}{|c|c|c|c|c|c|c|}
\hline References & 1 month & 1 year & 2 years & 3 years & 4 years & 5 years \\
\hline [21] & $94.9 \%$ & $66.7 \%$ & $57.7 \%$ & $50.4 \%$ & $42.3 \%$ & $39.9 \%$ \\
\hline [22] & $95 \%$ & $91.5 \%$ & & $83.1 \%$ & & \\
\hline [23] Non-hemodialysis group & $100 \%$ & $83 \pm 3 \%$ & $76 \pm 3 \%$ & $67 \pm 4 \%$ & & \\
\hline [23] Hemodialysis group & $98 \%$ & $70 \pm 6 \%$ & $53 \pm 7 \%$ & $45 \pm 8 \%$ & & \\
\hline [24] & $94 \%$ & $70.6 \%$ & & & & \\
\hline [25] & & $83 \%$ & & $64 \%$ & & $49 \%$ \\
\hline [26] & $97.2 \%$ & $82.9 \%$ & & $62.4 \%$ & & \\
\hline [26] Minor tissue loss group & & $74.9 \pm 2.6 \%$ & $63.7 \pm 3.2 \%$ & $54.0 \pm 3.7 \%$ & & \\
\hline [26] Major tissue loss group & & $65.4 \pm 5.2 \%$ & $45.7 \pm 6.4 \%$ & $37.3 \pm 7.7 \%$ & & \\
\hline [28] & & $80.6 \%$ & & & & \\
\hline [29] & & & & $70.7 \%$ & & \\
\hline [30] Non-amputated group & $97 \%$ & $81 \%$ & & & & \\
\hline [30] Amputated group & & $64 \%$ & & & & \\
\hline
\end{tabular}

\section{Discussion}

\section{Summary}

In this review, we summarized the findings on predictive factors for wound healing, AFS and survival in CLI patients who underwent a PTA. As stated, the data were heterogeneously reported and presented. In addition, none of the studies found the same predictive factors. However, in several studies age and diabetes were found as predictive factors for AFS or limb salvage and survival. Several univariate studies showed age and diabetes as predictors [12, 31-33].

\section{Compared with Other Studies}

To our knowledge, no such systematic review has been published. There is a review [34] in which the authors 
Table 10 Prediction factors by outcome

\begin{tabular}{|c|c|c|}
\hline References & Factors found to be significant in univariate analysis & Factors predictive (with p-values) \\
\hline \multicolumn{3}{|l|}{ Ulcer healing } \\
\hline \multirow[t]{5}{*}{ [22] } & $\frac{\text { Univariate analysis by fisher exact test, Chi-square test, }}{\underline{\text { Student's t test }(p<0.05)}}$ & $\underline{\text { Stepwise multiple logistic regression }}$ \\
\hline & Diabetes duration $(p=0.05)$ & HbA1c $(p=0.001)$ \\
\hline & $\operatorname{HbA1c}(p=0.002)$ & Serum creatinine levels $(p=0.03)$ \\
\hline & Creatinine $(p=0.04)$ & \\
\hline & Site of recent canalization $(p=0.03)$ & \\
\hline \multirow[t]{3}{*}{ [28] } & $\underline{\text { Univariate analysis, logistic regression }}$ & $\underline{\text { Not available }}$ \\
\hline & Skin perfusion pressure $(p=0.022)$ & \\
\hline & Ankle-brachial Index $(p>0.05)$ & \\
\hline \multicolumn{3}{|l|}{ AFS or limb salvage } \\
\hline$[21]^{\mathrm{a}}$ & $\frac{\text { Univariate analysis by fisher exact test, Chi-square, Mann- }}{\text { Whitney U test and Kaplan-Meier method }(\underline{p<0.05)}}$ & $\underline{\text { Cox regression with backward selection }}$ \\
\hline \multirow[t]{7}{*}{ AFS at 2 years } & Age $(p<0.004)$ & $\begin{array}{l}\text { AFS decreased for increased age, decreased EGR, } \\
\text { diabetes, coronary artery disease and bypass surgery }\end{array}$ \\
\hline & EGFR $(p=0.015)$ & \\
\hline & Diabetes $(p=0.003)$ & \\
\hline & Coronary artery disease $(p=0.004)$ & \\
\hline & Foot gangrene $(p=0.025)$ & \\
\hline & Level of vascularization $(p=0.004)$ & \\
\hline & Technique of revascularization $(p=0.005)$ & \\
\hline [23] & $\frac{\text { Univariate analysis in Kaplan-Meier and log rank or }}{\underline{\text { associations }}(\underline{p<0.05)}}$ & Cox proportional regression analysis \\
\hline \multirow{2}{*}{$\begin{array}{l}\text { Limb salvage (only } \\
\text { hemodialysis } \\
\text { group) }\end{array}$} & $\begin{array}{l}\text { Improvements in hemodynamics after intervention } \\
\quad(p=0.02)\end{array}$ & $\begin{array}{l}\text { Improvements in hemodynamics after intervention } \\
\quad(p=0.009)\end{array}$ \\
\hline & Improvement in symptoms $(p=0.02)$ & Improvement in symptoms $(p<0.001)$ \\
\hline \multirow{9}{*}{$\begin{array}{l}\text { [23] AFS (only } \\
\text { hemodialysis } \\
\text { group) }\end{array}$} & $\frac{\text { Univariate analysis in Kaplan-Meier and log rank or }}{\underline{\text { associations }(p<0.05)}}$ & $\underline{\text { Cox proportional regression analysis }}$ \\
\hline & Presence of hyperlipidemia $(p=0.006)$ & MACE $(p=0.005)$ \\
\hline & Cerebrovascular disease $(p=0.008)$ & Metabolic syndrome $(p=0.02)$ \\
\hline & Diabetes $(p<0.001)$ & \\
\hline & Metabolic syndrome $(p<0.001)$ & \\
\hline & Modified cardiac risk $(p=0.02)$ & \\
\hline & High-risk group $(p=0.04)$ & \\
\hline & Presence of MACE $(p=0.02)$ & \\
\hline & Elevated Finn score $(p=0.03)$ & \\
\hline [24] & $\underline{\text { Not available }}$ & $\underline{\text { Cox proportional regression analysis }}$ \\
\hline \multirow[t]{2}{*}{ Limb salvage } & & Advanced age \\
\hline & & Diabetes \\
\hline [25] & $\frac{\text { Univariate analysis using Kaplan-Meier and log rank }}{(\underline{p<0.05)}}$ & Cox proportional regression analysis \\
\hline \multirow[t]{4}{*}{ Limb salvage } & TASC class $(p=0.006)$ & TASC class $(p=0.031)$ \\
\hline & Not being a candidate for bypass $(p<0.001)$ & Not being a candidate for bypass $(p<0.001)$ \\
\hline & Dialysis $(p<0.001)$ & \\
\hline & Serum $>2.0 \mathrm{mg} / \mathrm{dl}(p=0.02)$ & \\
\hline [26] & 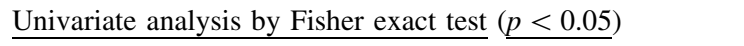 & Not available \\
\hline
\end{tabular}


Table 10 continued

\begin{tabular}{|c|c|c|}
\hline References & Factors found to be significant in univariate analysis & $\begin{array}{l}\text { Factors predictive (with } \\
\text { p-values) }\end{array}$ \\
\hline AFS at 1 year & $\begin{array}{l}\text { Coronary artery disease }(p<0.001) \\
\text { Rutherford category }(p<0.001) \\
\text { Renal disease }(p=0.030)\end{array}$ & \\
\hline [26] & 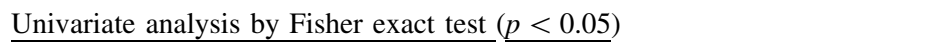 & $\underline{\text { Not available }}$ \\
\hline AFS at 3 year & $\begin{array}{l}\text { Age }<60(p=0.015) \\
\text { Coronary artery disease }(p<0.001) \\
\text { Rutherford category }(p<0.001) \\
\text { Diabetes }(p<0.003) \\
\text { Renal disease }(p=0.001)\end{array}$ & \\
\hline [26] & Univariate analysis by Fisher exact test $(\underline{p<0.05)}$ & $\underline{\text { Not available }}$ \\
\hline Limb salvage & $\begin{array}{l}\text { Rutherford category }(p=0.016) \\
\text { Diabetes }(P=0.020)\end{array}$ & \\
\hline [26] & $\underline{\text { Univariate analysis, Kaplan-Meier method and log rank }} \underline{(p<0.05)}$ & $\frac{\text { Cox proportional regression }}{\text { analysis }}$ \\
\hline \multirow{7}{*}{$\begin{array}{l}\text { Major amputation (Minor } \\
\text { tissue loss group) }\end{array}$} & Age $<60(p=0.003)$ & Age $<60(p=0.014)$ \\
\hline & Nonambulatory $(p=0.036)$ & $\mathrm{HbA} 1 \mathrm{c} \geq 6.8 \%(p=0.026)$ \\
\hline & Hyperlipidemia $(p=0.027)$ & $\begin{array}{l}\text { C-reactive protein }>5.0 \mathrm{mg} / \\
\quad \mathrm{dl}(p<0.001)\end{array}$ \\
\hline & $\operatorname{HbA} 1 \mathrm{c} \geq 6.8 \%(p<0.001)$ & $\begin{array}{l}\text { Albumin }<3.0 \mathrm{~g} / \mathrm{dl} \\
\quad(p=0.007)\end{array}$ \\
\hline & C-reactive protein $>5.0 \mathrm{mg} / \mathrm{dl}(p<0.001)$ & \\
\hline & Albumin $<3.0 \mathrm{~g} / \mathrm{dl}(p<0.001)$ & \\
\hline & Achieving technical success $(p=0.049)$ & \\
\hline [26] & 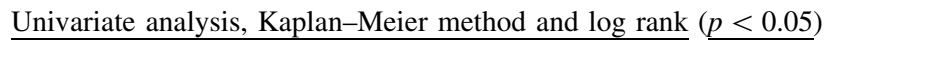 & $\frac{\text { Cox proportional regression }}{\underline{\text { analysis }}}$ \\
\hline \multirow{2}{*}{$\begin{array}{l}\text { Major amputation (Major } \\
\text { tissue loss group) }\end{array}$} & Nonambulatory $(p<0.001)$ & Nonambulatory $(p<0.001)$ \\
\hline & $\begin{array}{l}\text { Heel location }(p=0.05) \\
\text { Calcified lesions }(p=0.048)\end{array}$ & Calcified lesions $(p=0.029)$ \\
\hline [28] & Univariate analysis, logistic regression & Not available \\
\hline AFS at 1 year & $\begin{array}{l}\text { Skin perfusion pressure }(p=0.018) \\
\text { Ankle-brachial index }(p>0.05)\end{array}$ & \\
\hline$[29]^{\mathrm{b}}$ Limb salvage & Not available & $\begin{array}{l}\text { Cox proportional regression } \\
\text { analysis } \\
\text { No factors identified (tested) }\end{array}$ \\
\hline \multirow{2}{*}{$\begin{array}{l}\text { [30] Overall amputation or } \\
\text { major amputation }\end{array}$} & Univariate analysis by Fisher exact test $(p<0.05)$ & Not available \\
\hline & None of the factors tested was significant & \\
\hline \multicolumn{3}{|l|}{ Survival } \\
\hline [22] & $\frac{\text { Univariate analysis by fisher exact test, Chi-square test, Student's t test and }}{\underline{\text { Kaplan-Meier and log rank }(p<0.05)}}$ & $\frac{\text { Cox proportional regression }}{\underline{\text { analysis }}}$ \\
\hline \multirow[t]{2}{*}{ Survival } & $\begin{array}{l}\text { Age }(p=0.002) \\
\text { Creatinine }(p=0.004)\end{array}$ & Age $(p=0.0001)$ \\
\hline & Ulcer healing $(p=0.03)$ & Ulcer healing $(p=0.008)$ \\
\hline [23] & 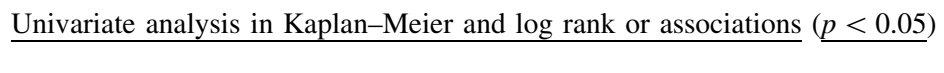 & $\frac{\text { Cox proportional regression }}{\text { analysis }}$ \\
\hline
\end{tabular}


Table 10 continued

\begin{tabular}{|c|c|c|}
\hline References & Factors found to be significant in univariate analysis & Factors predictive (with p-values) \\
\hline \multirow{5}{*}{$\begin{array}{l}\text { Survival (only hemodialysis } \\
\text { group) }\end{array}$} & Cerebrovascular disease $(p=0.014)$ & Presence of MACE $(p=0.04)$ \\
\hline & Diabetes $(p=0.003)$ & Major limb loss $(p=0.04)$ \\
\hline & Presence of hyperlipidemia $(p=0.04)$ & \\
\hline & Presence of MACE $(p=0.005)$ & \\
\hline & Major limb loss $(p=0.008)$ & \\
\hline [25] & $\frac{\text { Univariate analysis using Kaplan-Meier and log rank }}{(\underline{p<0.05)}}$ & Cox proportional regression analysis \\
\hline \multirow[t]{5}{*}{ Survival } & Factors not given & Age $71-80$ years $(p=0.042)$ \\
\hline & & Age $>80(p<0.001)$ \\
\hline & & Serum creat $>2.0 \mathrm{mg} / \mathrm{dl}(p=0.038)$ \\
\hline & & Congestive heart failure $(\mathrm{p}=0.04)$ \\
\hline & & $\begin{array}{l}\text { Not being a candidate for bypass } \\
\quad(p=0.002)\end{array}$ \\
\hline [26] & Univariate analysis by Fisher exact test $(\underline{p<0.05)}$ & Not available \\
\hline \multirow[t]{5}{*}{ Survival at 3 year } & Age $(p=0.003)$ & \\
\hline & Coronary artery disease $(p<0.001)$ & \\
\hline & Rutherford category $(p<0.001)$ & \\
\hline & Diabetes $(p=0.007)$ & \\
\hline & Renal disease $(p=0.005)$ & \\
\hline$[29]^{* *}$ & $\underline{\text { Not available }}$ & Cox proportional regression analysis \\
\hline Survival & & No factors identified (tested) \\
\hline$[30]$ & Univariate analysis by Fisher exact test $(p<0.05)$ & Not available \\
\hline (Death < 1 year) & None of the factors tested was significant & \\
\hline
\end{tabular}

${ }^{a}$ In this study, although data (ulcer healing, AFS or survival) were reported separately for PTA, data of regression analysis was presented combined both groups: PTA and bypass surgery

${ }^{\mathrm{b}}$ In this study, although data (ulcer healing, AFS or survival) were reported separately for PTA with Bare Metal Stent (BMS), data of regression analysis was presented for both PTA with BMS and PTA with drug eluting stent. The cox regression showed no difference between both groups

summarized risk stratification models for CLI with a summary of the respective strengths and limitations of each. These models were developed from prospective cohorts to identify and quantify variables that can subsequently predict outcome in individual patients. In the prospective cohort, treatment options generally were compared (e.g., open and endovascular therapies) and new therapeutics were evaluated. The outcomes were not specific for defining risk models in patients with CLI patients undergoing PTA.

\section{Strength of this Review}

The major strength of our study is that we focussed on patients with CLI who underwent PTA to identify possible predictive factors for clinically relevant outcomes. We have done this to create a homogeneous and clinically relevant population, in order to draw conclusions.

We included studies which aimed to study predictive values of all types of risk factors. In addition, we only selected prospective studies or studies that used a prospective database, to have a predefined design without missing a lot of data. It is known that missing data are much more common in retrospective studies, in which routinely collected data are subsequently used for a different purpose [35].

\section{Limitations of this Review}

Although all studies were performed prospectively or a prospective database was present with a spectrum of patients which are represented, the data were presented too heterogeneously. Even the AFS or survival analysis was not reported homogeneously. The presented data on the predictive values varied even more, making general conclusions difficult.

\section{Conclusion and Recommendations}

It is not clear which risk factors should be taken into account. However, in several studies two factors, age and diabetes, were found as predictive factors for AFS or limb 
salvage and survival in patients with CLI undergoing PTA. Therefore, we believe that these factors should be taken into account in the future when searching for predictive factors and when analyzing study data on endovascular treatments for CLI. More research on this topic is needed. A trial with registry of all risk factors and the outcomes up to 12 months would be very important. Future research is needed to simplify and improve the accuracy and generalizability of risk stratification in CLI.

\section{Compliance with Ethical Standards}

Conflict of interest S.M. Schreuder, Y.M.G.A. Hendrix, J.A. Reekers and S. Bipat declare that they have no conflict of interest.

Ethical Approval This article does not contain any studies with human participants or animals performed by any of the authors.

Informed Consent Does not apply.

Open Access This article is distributed under the terms of the Creative Commons Attribution 4.0 International License (http:// creativecommons.org/licenses/by/4.0/), which permits unrestricted use, distribution, and reproduction in any medium, provided you give appropriate credit to the original author(s) and the source, provide a link to the Creative Commons license, and indicate if changes were made.

\section{Appendix 1}

See Table 11

Table 11 Details search strategy

\begin{tabular}{|c|c|c|}
\hline \multicolumn{2}{|c|}{ Search terms } & $\begin{array}{l}\text { Number of } \\
\text { hits }\end{array}$ \\
\hline \multicolumn{3}{|c|}{ PUBMED } \\
\hline \#1 & $\begin{array}{l}\text { Search "Critical limb ischemia OR critical limb } \\
\text { ischemia" }\end{array}$ & 4246 \\
\hline \#2 & $\begin{array}{l}\text { Search (angioplasty OR endovascular } \\
\text { revascularization OR percutaneous intentional } \\
\text { extraluminal revascularization OR subintimal } \\
\text { OR endovascular therapy) }\end{array}$ & 95,820 \\
\hline \#3 & $\begin{array}{l}\text { Search (major amputation OR amputation free } \\
\text { survival OR death OR ulcer healing OR wound } \\
\text { healing OR mortality OR survival) }\end{array}$ & $2,061,511$ \\
\hline \#4 & Search (\#1 AND \#2 AND \#3) & 915 \\
\hline \#5 & $\begin{array}{l}\text { Search (\#1 AND \#2 AND \#3) Sort } \\
\text { by: Relevance Filters: published between } \\
\text { January } 2006 \text { and April 2017; Humans }\end{array}$ & 734 \\
\hline \multicolumn{3}{|c|}{$E M B A S E$} \\
\hline \#1 & $\begin{array}{l}\text { critical limb ischemia.mp. OR *critical limb } \\
\text { ischemia }\end{array}$ & 2669 \\
\hline$\# 2$ & $\begin{array}{l}\text { *percutaneous transluminal angioplasty balloon/ or } \\
\text { *percutaneous transluminal angioplasty/ or } \\
\text { *angioplasty }\end{array}$ & 72,918 \\
\hline
\end{tabular}

Table 11 continued

\begin{tabular}{|c|c|c|}
\hline \multicolumn{2}{|c|}{ Search terms } & \multirow{2}{*}{$\begin{array}{l}\text { Number of } \\
\text { hits }\end{array}$} \\
\hline \#3 & *Stent/ or *revascularization & \\
\hline \#4 & *mortality & 812,936 \\
\hline \#5 & $\begin{array}{l}\text { *amputation/ or major amputation.mp. or *leg } \\
\text { amputation }\end{array}$ & 47,732 \\
\hline \#6 & *Ulcer healing or *wound healing & 132,836 \\
\hline \#7 & *Survival & 770,209 \\
\hline$\# 8$ & $\begin{array}{l}\text { \#1 AND (\#2 OR \#3) AND (\#4 OR \#5 OR \#6 OR } \\
\text { \#7) published between January } 2006 \text { and April } \\
2017\end{array}$ & 901 \\
\hline
\end{tabular}

\section{References}

1. Michaels J. Second European Consensus Document on chronic critical leg ischemia. Eur J Vasc Surg. 1992;6 Suppl A:1-32.

2. Norgren L, Hiatt WR, Dormandy JA, Nehler MR, Harris KA, Fowkes FG, TASC II Working Group. Inter-society consensus for the management of peripheral arterial disease (TASC II). J Vasc Surg. 2007;45 Suppl S:S5-67.

3. Feiring AJ. Footnotes on critical limb ischemia. J Am Coll Cardiol. 2008;51(20):1975-6.

4. Teraa M, Conte MS, Moll FL, Verhaar MC. Critical limb ischemia: current trends and future directions. J Am Heart Assoc. 2016;5(2):e002938. doi:10.1161/JAHA.115.002938.

5. Blevins WA Jr, Schneider PA. Endovascular management of critical limb ischemia. Eur $J$ Vasc Endovasc Surg. 2010;39(6):756-61.

6. Beard JD. Which is the best revascularization for critical limb ischemia: endovascular or open surgery? J Vasc Surg. 2008;48(6 Suppl):11S-6S.

7. Söderström MI, Arvela EM, Korhonen M, Halmesmäki KH, Albäck AN, Biancari F, et al. Infrapopliteal percutaneous transluminal angioplasty versus bypass surgery as first-line strategies in critical leg ischemia: a propensity score analysis. Ann Surg. 2010;252(5):765-73.

8. Conrad MF, Kang J, Cambria RP, Brewster DC, Watkins MT, Kwolek CJ, et al. Infrapopliteal balloon angioplasty for the treatment of chronic occlusive disease. J Vasc Surg. 2009;50(4):799.e4-805.e4.

9. Haider SN, Kavanagh EG, Forlee M, Colgan MP, Madhavan P, Moore DJ, et al. Two-year outcome with preferential use of infrainguinal angioplasty for critical ischemia. J Vasc Surg. 2006;43(3):504-12.

10. Faglia E, Dalla Paola L, Clerici G, Clerissi J, Graziani L, Fusaro $\mathrm{M}$, et al. Peripheral angioplasty as the first-choice revascularization procedure in diabetic patients with critical limb ischemia: prospective study of 993 consecutive patients hospitalized and followed between 1999 and 2003. Eur J Vasc Endovasc Surg. 2005;29(6):620-7.

11. Dosluoglu HH, Lall P, Harris LM, Dryjski ML. Long-term limb salvage and survival after endovascular and open revascularization for critical limb ischemia after adoption of endovascular-first approach by vascular surgeons. J Vasc Surg. 2012;56(2):361-71.

12. Faglia E, Clerici G, Airoldi F, Tavano D, Caminiti M, Curci V, et al. Revascularization by angioplasty of type D femoropopliteal and long infrapopliteal lesion in diabetic patients with critical limb ischemia: are TASC II recommendations suitable? A population-based cohort study. Int $\mathrm{J}$ Low Extrem Wounds. 2012;11(4):277-85. 
13. Gallagher KA, Meltzer AJ, Ravin RA, Graham A, Shrikhande G, Connolly PH, et al. Endovascular management as first therapy for chronic total occlusion of the lower extremity arteries: comparison of balloon angioplasty, stenting, and directional atherectomy. J Endovasc Ther. 2011;18(5):624-37. Erratum in: J Endovasc Ther. 2011;18(6):A-5.

14. Iida O, Soga Y, Yamauchi Y, Hirano K, Kawasaki D, Yamaoka $\mathrm{T}$, et al. Clinical efficacy of endovascular therapy for patients with critical limb ischemia attributable to pure isolated infrapopliteal lesions. J Vasc Surg. 2013;57(4):974.e1-981.e1.

15. Tomoi Y, Soga Y, Iida O, Hirano K, Suzuki K, Kawasaki D, et al. Efficacy of statin treatment after endovascular therapy for isolated below-the-knee disease in patients with critical limb ischemia. Cardiovasc Interv Ther. 2013;28(4):374-82.

16. Rastan A, Tepe G, Krankenberg H, Zahorsky R, Beschorner U, Noory E, et al. Sirolimus-eluting stents vs. bare-metal stents for treatment of focal lesions in infrapopliteal arteries: a doubleblind, multi-centre, randomized clinical trial. Eur Heart J. 2011;32(18):2274-81.

17. Schmidt A, Ulrich M, Winkler B, Klaeffling C, Bausback Y, Bräunlich $S$, et al. Angiographic patency and clinical outcome after balloon-angioplasty for extensive infrapopliteal arterial disease. Catheter Cardiovasc Interv. 2010;76(7):1047-54.

18. Treiman GS, Treiman R, Whiting J. Results of percutaneous subintimal angioplasty using routine stenting. J Vasc Surg. 2006;43(3):513-9.

19. Smith BM, Stechman M, Gibson M, Torrie EP, Magee TR, Galland RB. Subintimal angioplasty for superficial femoral artery occlusion: poor patency in critical ischaemia. Ann R Coll Surg Engl. 2005;87(5):361-5.

20. Liberati A, Altman DG, Tetzlaff J, Mulrow C, Gøtzsche PC, Ioannidis JP, et al. The PRISMA statement for reporting systematic reviews and meta-analyses of studies that evaluate healthcare interventions: explanation and elaboration. BMJ. 2009;21(339):b2700.

21. Arvela E, Venermo M, Söderström M, Korhonen M, Halmesmäki $\mathrm{K}$, Albäck A, et al. Infrainguinal percutaneous transluminal angioplasty or bypass surgery in patients aged 80 years and older with critical leg ischaemia. Br J Surg. 2011;98(4):518-26.

22. Bargellini I, Petruzzi P, Scatena A, Cioni R, Cicorelli A, Vignali C, et al. Primary infrainguinal subintimal angioplasty in diabetic patients. Cardiovasc Interv Radiol. 2008;31(4):713-22.

23. Davies MG, El-Sayed HF. Outcomes of isolated tibial endovascular interventions for tissue loss in CLI patients on hemodialysis. J Endovasc Ther. 2015;22(5):681-9.
24. Dick F, Diehm N, Galimanis A, Husmann M, Schmidli J, Baumgartner I. Surgical or endovascular revascularization in patients with critical limb ischemia: influence of diabetes mellitus on clinical outcome. J Vasc Surg. 2007;45(4):751-61.

25. Lo RC, Darling J, Bensley RP, Giles KA, Dahlberg SE, Hamdan $\mathrm{AD}$, et al. Outcomes following infrapopliteal angioplasty for critical limb ischemia. J Vasc Surg. 2013;57(6):1455-63 discussion 1463-4.

26. Mathur K, Ayyappan MK, Hodson J, Hopkins J, Tiwari A, Duddy $\mathrm{M}$, et al. Factors affecting medium-term outcomes after crural angioplasty in critically ischemic legs. Vasc Endovascular Surg. 2015;49(3-4):63-8.

27. Nakano M, Hirano K, Yamauchi Y, Iida O, Soga Y, Kawasaki D, et al. Three-year clinical outcome after infrapopliteal angioplasty for critical limb ischemia in hemodialysis patients with minor or major tissue loss. Catheter Cardiovasc Interv. 2015;86(2):289-98.

28. Okamoto S, Iida O, Nakamura M, Yamauchi Y, Fukunaga M, Yokoi Y, et al. Postprocedural skin perfusion pressure correlates with clinical outcomes 1 year after endovascular therapy for patients with critical limb ischemia. Angiology. 2015;66(9): $862-6$.

29. Siablis D, Karnabatidis D, Katsanos K, Diamantopoulos A, Spiliopoulos S, Kagadis GC, Tsolakis J. Infrapopliteal application of sirolimus-eluting versus bare metal stents for critical limb ischemia: analysis of long-term angiographic and clinical outcome. J Vasc Interv Radiol. 2009;20(9):1141-50.

30. Strøm M, Konge L, Lönn L, Schroeder TV, Rørdam P. Amputation-free survival after crural percutaneous transluminal angioplasty for critical limb ischemia. Scand $\mathrm{J}$ Surg. 2016;105(1):42-8.

31. Bakken AM, Palchik E, Hart JP, Rhodes JM, Saad WE, Davies MG. Impact of diabetes mellitus on outcomes of superficial femoral artery endoluminal interventions. $J$ Vasc Surg. 2007;46(5):946-58 discussion 958.

32. Brosi P, Dick F, Do DD, Schmidli J, Baumgartner I, Diehm N. Revascularization for chronic critical lower limb ischemia in octogenarians is worthwhile. J Vasc Surg. 2007;46(6):1198-207.

33. Setacci F, Sirignano P, Raucci A, de Donato G, Chisci E, Galzerano $\mathrm{G}$, et al. Below the knee endovascular revascularization strategy for limb salvage in diabetic patients. Ital J Vasc Endovasc Surg. 2010;17(3):189-94.

34. Chung J, Modrall JG, Valentine RJ. The need for improved risk stratification in chronic critical limb ischemia. J Vasc Surg. 2014;60(6):1677-85.

35. Altman DG, Bland JM. Missing data. BMJ. 2007;334(7590):424. 